\title{
A Micro-climatic Observation in the Extremely Hot and Dry Climate in Iraq*
}

\author{
Hiroshi ITo \\ (Department of Physiology and Genetics National Institute \\ of Agricultural Sciences Hiratsuka, Kanagawa)
}

\begin{abstract}
Natural conditions in Iraq are not unsuitable for rice growing, except for the extremely high temperature and low humidity during the rice growing season. The extremely high temperature and low humidity may, however, be modified well suitable for rice production by concentrating rice fields in large, well irrigated areas protected by windbreaks.
\end{abstract}

\section{Introduction}

To consider the agriculture or rice culture in any country, it is better to analyse the environment under the heading of i) climate, ii) soil and iii) biological environment of the fields. The main difference between Iraq and other rice growing countries exists in climate. Rice originated in South-East Asia where the rice growing season is very hot and highly humid, but in Iraq the climate during the rice growing season is extremely hot and very dry. Therefore, it is necessary to give special attention to the climate. In particular, the local climate in the rice growing areas and the micro-climate in the rice field or the rice plant itself are especially important. The record of the Government of Iraq indicates that the monthly average of the daily maximum air temperature at meteorological observatories are about $42^{\circ} \mathrm{C}$ and that the monthly average of the daily minumum relative humidity are about $20 \%$. It has been found that in such a dry condition the development of rice grain is impossible. In spite of these facts, however, in Iraq the average annual yield of rice grains attains to 100,000 tons. This is one of the greatest miracles in modern agriculture, and can only be explained by the fact that the temperature of the rice plants themselves is not necessarily as high as the air temperature recorded at the Meteorological Observatories, the Government of Iraq.

\section{Materials and methods}

* Read at the Annual General Meeting
Tokyo, on 8 th April 1964
A. Local climatic observation in the rice field areas.

The local climate in the rice field areas with the high and low yields were selected and observed, respectively. A high yield area was selected in the surroundings of Shamiah Town located about $200 \mathrm{~km}$ apart to the south from Baghdad City. In this area, $69 \mathrm{~km}$ trip from the desert near Najaf City to the desert near Diwaniya City including $25 \mathrm{~km}$ distance of paddy field, marsh and other aquatic area surronding Shamiah Town was done. The first observation was made between 2 and 5 p. m. on $3 \mathrm{rd}$ August and the second between 11 a.m. and 2 p.m. on 7 th September, 1963. At the time of the first observation, the predominant rice variety named "Ambar" was at the most effective tillering stage and the others, named "Nayima" was at the heading and named "Hauezawi" was at the maturity stages. And at the time of the second observation, "Ambar" was just at the heading and "Nayima" was already harvested. The temperature and relative humidity $1 \mathrm{~m}$ above the surface at the side of road at each observation point were measured with Asman's psychrometer of $1^{\circ} \mathrm{C}$ graduation. In August, one observation point was selected in each typical condition by the road, i.e. desert, town, canal, paddy field, marsh etc., so the results obtained were discontinuous and it was inevitable to show the result as bars. In September, at point $5 \mathrm{~km}$ apart in the desert and grass land, and at point $2 \mathrm{~km}$ apart in the rice field area and marsh, observations were undertaken, so the results obtained were given as a broken line.

A low yield area is scattered along the international road from Iraq to Kuwait via Amara City. Among this road, the same kind of observation between 6 a.m. and 4 p.m. on 24 th August, 1963, at points $10 \mathrm{~km}$ apart for $400 \mathrm{~km}$ from Baghdad to Amara was done. The method of observation was almost same as the one mentioned above. 
B. Micro-climatic observations in a high yield paddy field and a typical desert for comparison.

Micro-climatic observations in a high yield paddy field and in a typical desert were carried out as a comparison. A paddy field located at Om-Arda, Al-Mishkhab, was selected as it has been said to produce about 4 tons/ha of rice in every year. It is $18 \mathrm{~km}$ apart from Abi-Sekhair Town to the south and is faciliated well with beautiful date palm grove as a windbreak in each 500 metres distance against north-west wind in summer. And a part of desert $1 \mathrm{~km}$ apart from Najaf City to the north east was selected. It is a typical desert and there is no meteorological obstacle surrounding this place, and the desert spreads in the windward direction as far as Syria. The observations were made on 5 th and 6 th August 1963 in the paddy field and 7 th and 8 th in the desert, respectively. The weather conditions during these four days were all fine but slightly dusty with wind, and we could consider the weather was the typical in summer.

The temperature and the relative humidity at heights of 2, 50, 100 and $150 \mathrm{~cm}$ above the soil, and the temperature of the soil surfaces with and without irrigation water and rice plants were recorded hourly, with Asman's psychrometer used for the observation of local climate for 24 hours. The wind velocity was also recorded by Beaufort scale with eye measurement. As it was an eye measurement, the wind record of the Diwaniya Meteorological Observatory was cited as a reference.

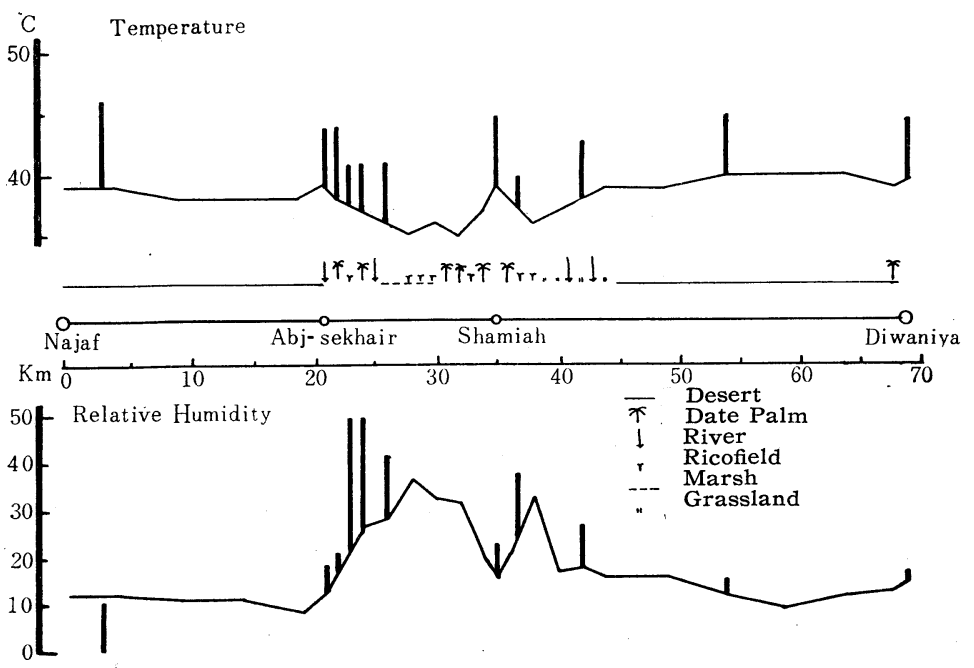

Fig. 1. Influence of collective rice field area on the desert climate.
Temperature of water at the bottom was regarded as the soil surface temperature with water. The depth of water was $3 \mathrm{~cm}$. For the measurement of rice plant temperature, standing rice plants in the field grasped by hand and in the center of plants a cylinder shape thermometer was inserted for about 30 seconds then another groups of plants were grasped and the thermometer was transfered in this: bundle. After three times of insertion mentioned above, the temperature of rice plant was determined.

Out of the above, observations of same kind were given on 9 th and 10 th September 1963 in the paddy field at Al-Mishkhab and on 11 th and 12 th September in the experimental paddy field at the Diwaniya Experimental Farm, additionally for a check of the results in August.

\section{Results}

A. Local climatic observation in the rice field areas.

Results obtained during two occasions of observation surrounding Shamiah, a high yield area, are illustrated in Figure 1.

In August, there was a temperature of $46^{\circ} \mathrm{C}$ with only $10 \%$ of humidity in the air 1 metre above the soil surface and $61^{\circ} \mathrm{C}$ of soil surface temperature in the desert area, from Najaf to Abi-Sekhair and there was almost no grass until the western limit of the Abi-Sekhair Town. This town is located at the western bank of a branch of the River Euphratis and there are so many date palm trees planted in the town. The temperature was $44^{\circ} \mathrm{C}$ with $18 \%$ of humidity on the road in this town. Beyond this town across the river about $25 \mathrm{~km}$ distance there are rice field area, marsh and brooks and the surface of this area is covered with water, rice plant, aquatic plants and date palm groves. In this area there was a temperature of $41^{\circ} \mathrm{C}$ with $49 \%$ of humidity and the temperature of water was $35^{\circ} \mathrm{C}$ in an average. But there is a town named Shamiah, where is the biggest rice market in Iraq, there was of $45^{\circ} \mathrm{C}$ with $22 \%$ of humidity even it is located in the center of aquatic area. The eastern 
limit of this rice field area is a big drainage canal. At the bank of this canal there was a temperature of $43^{\circ} \mathrm{C}$ with $26 \%$ of humidity but the soil temperature was still $55^{\circ} \mathrm{C}$ and the temperature of running water in the canal was $33^{\circ} \mathrm{C}$. From this canal the grass land continues to Diwaniya Town, but the species of grass gradually changed from cereals to fleshy plants in the desert. This is the big difference between the western and eastern sides of this aquatic area as the predominant summer wind is north-west direction in this area. At the distance of $18 \mathrm{~km}$ from the canal there grew only a fleshy plant with thorns and there was a temperature of $45^{\circ} \mathrm{C}$ with $14 \%$ of humidity. The body temperature of this fleshy plant was $43^{\circ} \mathrm{C}$. It was already 5 p.m. but the temperature at the Diwaniya Meteorological Observatory was $44.5^{\circ} \mathrm{C}$ with $16 \%$ of humidity.

In September, the same tendency was observed but this time the observation was more continuous than in August, and the results is shown as a broken line in Table 1.

Results obtained on 24 th August 1963 from Baghdad City to Amara City, where many low yield rice fields are scattered, are illustrated in Figure 2.

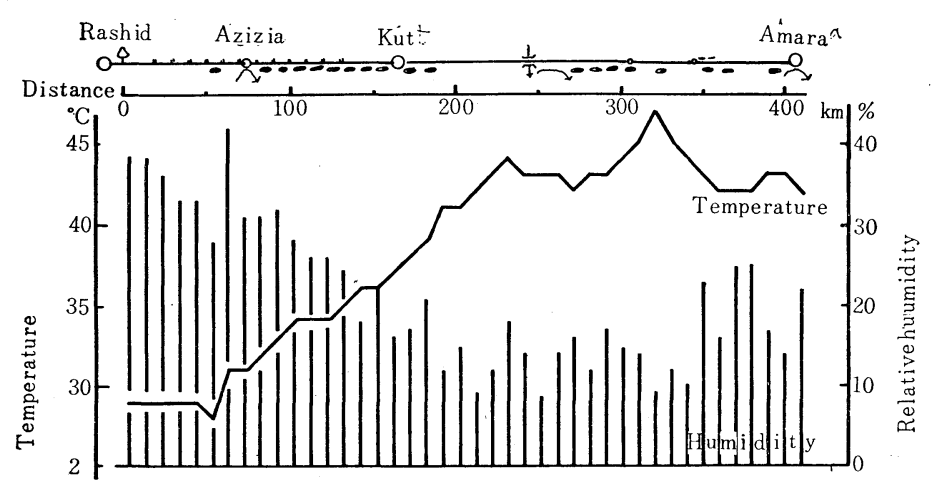

$$
\begin{aligned}
& \text { Time } \\
& \begin{array}{rl}
\hline 6 & 7 \\
\text { Remarks } & \text { o City } \\
& \circ \text { Town } \\
& \circ \text { Village }
\end{array} \\
& 8
\end{aligned}
$$

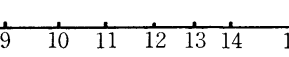

$$
\begin{aligned}
& \text { Q Forest } \rightarrow \text { River } \\
& \text { - Desert } \longrightarrow \text {. Giver Lass Land } \\
& \text { - Paddyfield =- Marsh }
\end{aligned}
$$

Fig. 2. Influence of scattered rice field area on the desert climate.$$
160 \text { O'clock }
$$

was $29^{\circ} \mathrm{C}$ and the humidity was $28 \%$. The car passed through the forest in the suburbs at $6: 15$ a. m., where the temperature was $29^{\circ} \mathrm{C}$ and the humidity $38 \%$. Later on, the temperature rised slowly up to $43^{\circ} \mathrm{C}$ and the humidity decreased down to $9 \%$. En route from Azizia Town to Kut City between about $8: 00$ to $8: 45$ a. m., there were many rice fields scattered along the road. No influence of rice field to the temperature on the road was observed. Same observation was made from $1: 00$ p.m. to $3: 00$ p.m. and there was also no influence, but the temperature in the rice field 1 metre above the soil surface was $40^{\circ} \mathrm{C}$ and the humidity $20 \%$. The water temperature was $36^{\circ} \mathrm{C}$ even though the temperature on the road was $43^{\circ} \mathrm{C}$ and the humidity $12 \%$. There is a small village on the road and the temperature was $44^{\circ} \mathrm{C}$ with the humidity of $13 \%$ on the street and inside a shop in this village the temperature was $43^{\circ} \mathrm{C}$ with the humidity of $17 \%$. It means that a small village gives no influence to the climate even though there was a big influence in the town of Shamiah. At 4: 00 p.m. by the marsh, the temperature was $42^{\circ} \mathrm{C}$ and the humidity was $25^{\circ} \mathrm{C}$. In the desert after passing this marsh, the temperature was $43^{\circ} \mathrm{C}$ and the humidity was 14\%. These results indicate that there was little climatic influence of rice fields to the weather on the road, since the size of rice fields scattered along the road were not so large compared to that surrounding Shamiah Town.

B. Micro-climatic observations in a high yield paddy field and in a typical desert for comparison.

Results obtained in a high yield on 5 th and 6 th August 1963 at A1-Mishkhab are given in Table 1.

The growth of rice plant was very vigorous and the height and the length were $60 \mathrm{~cm}$ and $74.4 \mathrm{~cm}$, respectively. The density of tillers was 730 per square metre. At $150 \mathrm{~cm}$ height the temperature was from $23^{\circ} \mathrm{C}$ to $39^{\circ} \mathrm{C}$ and the humidity was from $70 \%$ to $39 \%$. There was a bimodal curve in humidity. Under the cover of rice plants, bimodal curve in humidity was more obvious. At $50 \mathrm{~cm}$ height the temperature was from $22^{\circ} \mathrm{C}$ to $38^{\circ} \mathrm{C}$ and the humidity from $92 \%$ leave Baghdad in the early morning, so the record of this time was much influenced by the daily variation of temperature and humidity. Moreover, the day for observation was already the late August and the temperature was not so high as that of the observation in early August. The departure from Baghdad City was at 5:55 a.m.. The temperature 
Table 1. Micro-climate in the paddy field at Al-Mishkhab.

\begin{tabular}{|c|c|c|c|c|c|c|c|c|c|c|c|c|c|}
\hline \multirow{3}{*}{$\begin{array}{l}\text { Obs. } \\
\text { time }\end{array}$} & \multicolumn{10}{|c|}{ Temperature and (Relative humidity) } & \multirow{3}{*}{$\begin{array}{l}\text { Wind } \\
\text { velocity }\end{array}$} & \multicolumn{2}{|c|}{ Diwaniya Met. Obs. } \\
\hline & \multicolumn{8}{|c|}{ Height of observation $(\mathrm{cm})$} & \multirow{2}{*}{$\begin{array}{l}\text { Bottom } \\
\text { of water }\end{array}$} & \multirow{2}{*}{$\begin{array}{l}\text { Rice } \\
\text { plants }\end{array}$} & & \multirow{2}{*}{$\begin{array}{c}\text { Wind } \\
\text { direction }\end{array}$} & \multirow{2}{*}{$\begin{array}{c}\text { Wind } \\
\text { velocity }\end{array}$} \\
\hline & & 150 & & 100 & & 50 & & 2 & & & & & \\
\hline $\begin{array}{l}10 \\
11 \\
12\end{array}$ & & $\begin{array}{l}\% \% \\
(64) \\
(54) \\
(55)\end{array}$ & & $\begin{array}{l}\% \% \\
(69) \\
(64) \\
(65)\end{array}$ & $\begin{array}{l}{ }^{\circ} \mathrm{C} \\
33 \\
34 \\
35\end{array}$ & $\begin{array}{r}\% \\
(80) \\
(64) \\
(75)\end{array}$ & $\begin{array}{l}{ }^{\circ} \mathrm{C} \\
32 \\
32 \\
34\end{array}$ & $\begin{array}{l}\% \\
(86) \\
(86) \\
(87)\end{array}$ & $\begin{array}{l}{ }^{\circ} \mathrm{C} \\
30 \\
33 \\
35\end{array}$ & $\begin{array}{l}{ }^{\circ} \mathrm{C} \\
30 \\
33 \\
33\end{array}$ & $\begin{array}{c}\text { Beaufort } \\
0 \\
1 \\
1\end{array}$ & $\begin{array}{l}\mathrm{N} \\
\mathrm{N} \\
\mathrm{N}\end{array}$ & $\begin{array}{c}\text { Beaufort } \\
4 \\
4 \\
4\end{array}$ \\
\hline $\begin{array}{l}13 \\
14 \\
15\end{array}$ & & $\begin{array}{l}(55) \\
(56) \\
(56)\end{array}$ & & $\begin{array}{l}(60) \\
(56) \\
(61)\end{array}$ & $\begin{array}{l}36 \\
37 \\
38\end{array}$ & $\begin{array}{l}(65) \\
(76) \\
(71)\end{array}$ & & $\begin{array}{l}(81) \\
(81) \\
(70) \\
\end{array}$ & $\begin{array}{l}36 \\
39 \\
38\end{array}$ & $\frac{34}{34}$ & $\begin{array}{l}2 \\
1 \\
0\end{array}$ & $\begin{array}{l}\text { WNW } \\
\text { NNW } \\
\text { N }\end{array}$ & $\begin{array}{l}4 \\
2 \\
1\end{array}$ \\
\hline $\begin{array}{l}16 \\
17 \\
18\end{array}$ & $\begin{array}{l}38 \\
36 \\
35\end{array}$ & $\begin{array}{l}(61) \\
(60) \\
(54)\end{array}$ & $\begin{array}{l}38 \\
36 \\
34\end{array}$ & $\begin{array}{l}(61) \\
(65) \\
(69)\end{array}$ & $\begin{array}{l}37 \\
35 \\
32\end{array}$ & $\begin{array}{l}(71) \\
(70) \\
(86)\end{array}$ & & $\begin{array}{l}(87) \\
(87) \\
(93)\end{array}$ & $\begin{array}{l}36 \\
35 \\
34\end{array}$ & $\frac{\frac{34}{34}}{31}$ & $\begin{array}{l}0 \\
1 \\
0\end{array}$ & $\begin{array}{c}\mathrm{N} \\
\mathrm{NNW} \\
\mathrm{NNW}\end{array}$ & $\begin{array}{l}4 \\
3 \\
3\end{array}$ \\
\hline $\begin{array}{l}19 \\
20 \\
21\end{array}$ & $\begin{array}{l}32 \\
32 \\
31\end{array}$ & $\begin{array}{l}(52) \\
(41) \\
(40)\end{array}$ & $\begin{array}{l}31 \\
31 \\
31\end{array}$ & $\begin{array}{l}(67) \\
(45) \\
(40)\end{array}$ & $\begin{array}{l}30 \\
28 \\
29\end{array}$ & $\begin{array}{l}(73) \\
(59) \\
(54)\end{array}$ & $\begin{array}{l}29 \\
27 \\
27\end{array}$ & $\begin{array}{l}(100) \\
(92) \\
(92)\end{array}$ & $\begin{array}{l}32 \\
30 \\
30\end{array}$ & $\begin{array}{l}29 \\
27 \\
25\end{array}$ & $\begin{array}{l}1 \\
0 \\
0\end{array}$ & $\begin{array}{c}\text { NNW } \\
\mathrm{N} \\
\mathrm{N}\end{array}$ & $\begin{array}{l}3 \\
2 \\
3\end{array}$ \\
\hline $\begin{array}{l}22 \\
23 \\
24\end{array}$ & $\begin{array}{l}29 \\
30 \\
27\end{array}$ & $\begin{array}{l}(43) \\
\frac{(39)}{(65)}\end{array}$ & $\begin{array}{l}29 \\
30 \\
27\end{array}$ & $\begin{array}{l}(49) \\
(39) \\
(65)\end{array}$ & $\begin{array}{l}28 \\
29 \\
25\end{array}$ & $\begin{array}{l}(53) \\
\frac{(43)}{(84)}\end{array}$ & $\begin{array}{l}25 \\
25 \\
25\end{array}$ & $\begin{array}{l}(92) \\
(84) \\
(92)\end{array}$ & $\begin{array}{l}29 \\
28 \\
28\end{array}$ & $\begin{array}{l}25 \\
24 \\
25\end{array}$ & $\begin{array}{l}1 \\
1 \\
1\end{array}$ & $\frac{-}{N}$ & $\frac{-}{3}$ \\
\hline $\begin{array}{l}1 \\
2 \\
3\end{array}$ & $\begin{array}{l}26 \\
26 \\
26\end{array}$ & $\begin{array}{l}(58) \\
(51) \\
(51)\end{array}$ & $\begin{array}{l}26 \\
26 \\
26\end{array}$ & $\begin{array}{l}(58) \\
(51) \\
(51)\end{array}$ & $\begin{array}{l}25 \\
24 \\
25\end{array}$ & $\begin{array}{l}(76) \\
(62) \\
(63)\end{array}$ & & $\begin{array}{l}(92) \\
(92) \\
(84)\end{array}$ & $\begin{array}{l}27 \\
27 \\
26\end{array}$ & $\frac{\frac{22}{22}}{22}$ & $\begin{array}{l}2 \\
2 \\
2\end{array}$ & $\frac{-}{\bar{N}}$ & $\frac{-}{3}$ \\
\hline $\begin{array}{l}4 \\
5 \\
6\end{array}$ & $\begin{array}{l}25 \\
\frac{23}{24}\end{array}$ & $\begin{array}{l}(57) \\
\frac{(76)}{(70)}\end{array}$ & $\begin{array}{l}24 \\
\frac{23}{23} \\
\end{array}$ & $\begin{array}{l}(70) \\
(84) \\
(76)\end{array}$ & $\begin{array}{l}23 \\
\frac{22}{23}\end{array}$ & $\begin{array}{l}(84) \\
\frac{(92)}{(84)}\end{array}$ & $\begin{array}{l}22 \\
23 \\
22\end{array}$ & $\frac{(100)}{(100)}$ & $\begin{array}{l}25 \\
25 \\
23 \\
\end{array}$ & $\begin{array}{l}\overline{23} \\
23 \\
23\end{array}$ & $\begin{array}{l}0 \\
0 \\
0\end{array}$ & $\frac{-}{\mathrm{N}}$ & $\frac{-}{3}$ \\
\hline $\begin{array}{l}7 \\
8 \\
9\end{array}$ & $\begin{array}{l}27 \\
32 \\
34\end{array}$ & $\begin{array}{l}(52) \\
(46) \\
(48)\end{array}$ & $\begin{array}{l}26 \\
31 \\
33\end{array}$ & $\begin{array}{l}(58) \\
(51) \\
(52)\end{array}$ & $\begin{array}{l}26 \\
30 \\
32\end{array}$ & $\begin{array}{l}(71) \\
(61) \\
(68)\end{array}$ & $\begin{array}{l}24 \\
27 \\
31\end{array}$ & $\begin{array}{l}(92) \\
(92) \\
(80)\end{array}$ & $\begin{array}{l}26 \\
26 \\
27\end{array}$ & $\begin{array}{l}24 \\
27 \\
29\end{array}$ & $\begin{array}{l}1 \\
2 \\
2\end{array}$ & $\begin{array}{c}\text { NNW } \\
\mathrm{N} \\
\mathrm{N}\end{array}$ & $\begin{array}{l}4 \\
4 \\
4\end{array}$ \\
\hline 10 & 34 & (48) & 33 & (52) & 23 & (63) & 31 & (86) & 30 & 30 & 2 & NW & 4 \\
\hline
\end{tabular}

Remarks : 1. Date of observation : 5 6 August 1963.

Location: Om-Arda, Al-mishkhab, Abi-Sekhair, Diwaniya, IRAQ

2. Obs. time means time for observation.

3. Bottom of water means the soil surface with irrigated water in the paddy field.

4. Beaufort means Beaufort Scale of wind velocity.

5. Diwaniya Met. Obs. means the Diwaniya Meteorogical Observatory. at the Air Port.

to $43 \%$. At $2 \mathrm{~cm}$ height above the water surface the temperature was from $21^{\circ} \mathrm{C}$ to $36^{\circ} \mathrm{C}$ and the humidity from $100 \%$ to $70 \%$, and there was abundant dew both in the morning and in the evening. These dews were considered mainly come from the guttation of rice plants. One of the remarkable features of observations was the temperature of rice plant itself, which did not exceed $34^{\circ} \mathrm{C}$ even at the time of the maximum temperature of the day and did go down with the air temperature as low as the minumum air temperature. This observation shows that rice plants have the ability to protect themselves against rises in temperature but can not protect themselves against falls in temperature.

While making this observation, it was notable that the effect of the windbreaks surrounding the rice fields was to decrease considereably the force of the wind. Despite of the strong wind of Beaufort Scale 3 to 4 recorded at the Diwaniya Meteorological Observatory, the simultaneous wind over the paddy fields at A1-Mishkhab was fairly weak only of the scale of a dead calm as given in Table 1 .

Results obtained in the desert on 7 th and 8 th August 1963 near Najar City are given in Table 2.

The soil surface of the desert selected for observation was hard enough to drive an ordinary pickup car, but there was almost no grass surrounding the observation point.

The daily variations of temperature and humidity were going withtogether and no bimodal curve was observed. When the temperature of the surface of 
A Micro-climatic Observation in a Rice Field in the Extremely Hot and Dry Climate in Iraq 105

Table 2. Micro-climate in the desert near Najaf City.

\begin{tabular}{|c|c|c|c|c|c|c|c|c|c|c|c|c|}
\hline \multirow{3}{*}{$\begin{array}{l}\text { Obs. } \\
\text { time }\end{array}$} & \multicolumn{9}{|c|}{ Temperature and (Relative humidity) } & \multirow{3}{*}{$\begin{array}{l}\text { Wind } \\
\text { velocity }\end{array}$} & \multicolumn{2}{|c|}{ Diwaniya Met. Obs } \\
\hline & \multicolumn{8}{|c|}{ Height of observation $(\mathrm{cm})$} & \multirow{2}{*}{$\begin{array}{c}\text { Soil } \\
\text { surface }\end{array}$} & & \multirow{2}{*}{$\begin{array}{c}\text { Wind } \\
\text { direction }\end{array}$} & \multirow{2}{*}{$\begin{array}{l}\text { Wind } \\
\text { velocity }\end{array}$} \\
\hline & \multicolumn{2}{|c|}{150} & \multicolumn{2}{|c|}{100} & \multicolumn{2}{|r|}{50} & \multicolumn{2}{|r|}{2} & & & & \\
\hline 6 & & $\begin{array}{r}\% \\
(38) \\
\end{array}$ & & $\begin{array}{r}\% \\
(38) \\
\end{array}$ & & $\begin{array}{r}\% \\
(33)\end{array}$ & $\begin{array}{l}{ }^{\circ} \mathrm{C} \\
29\end{array}$ & $\begin{array}{l}\% \\
(33)\end{array}$ & $\begin{array}{l}{ }^{\circ} \mathrm{C} \\
28\end{array}$ & $\begin{array}{c}\text { Beaufort } \\
3\end{array}$ & WNW & $\begin{array}{c}\text { Beaufort } \\
3\end{array}$ \\
\hline 7 & & $(24)$ & & $\overline{(24)}$ & & $(28)$ & & $(28)$ & 32 & 3 & NW & 3 \\
\hline 8 & & $(21)$ & & $(25)$ & & $(25)$ & & $(34)$ & 38 & 3 & NNW & 3 \\
\hline 9 & & (17) & & $(20)$ & 38 & $(20)$ & 39 & $(21)$ & 44 & 4 & NNW & 3 \\
\hline 10 & 39 & (15) & 39 & (18) & 40 & $(14)$ & 42 & $(22)$ & 48 & 4 & NW & 4 \\
\hline 11 & & (12) & & (15) & & (15) & 44 & (18) & 53 & 4 & NW & 4 \\
\hline 12 & & (13) & 42 & (11) & 42 & (16) & 44 & (18) & 56 & 4 & WNW & 4 \\
\hline 13 & 42 & (11) & 43 & (14) & 44 & $(9)$ & 47 & (11) & 57 & 4 & NNW & 4 \\
\hline 14 & & (12) & 44 & (10) & $\overline{44}$ & (12) & $\overline{47}$ & ( 7 ) & $\frac{11}{56}$ & 4 & NNW & 4 \\
\hline 15 & & $\underline{(10)}$ & $\underline{44}$ & (10) & $\overline{44}$ & (8) & $\overline{46}$ & $\frac{\overline{1}}{(10)}$ & 55 & 4 & WWN & 4 \\
\hline 16 & & $\overline{(12)}$ & $\overline{44}$ & $\overline{(13)}$ & $\overline{44}$ & $\overline{(13)}$ & 45 & ( 7$)$ & 52 & 4 & NNW & 4 \\
\hline 17 & & (17) & $\overline{43}$ & (20) & & (14) & 44 & $\overline{(18)}$ & 49 & 4 & WNW & 4 \\
\hline 18 & & (16) & 42 & (13) & 42 & (13) & 42 & (16) & 44 & 4 & WNW & 4 \\
\hline 19 & 40 & (14) & 39 & (18) & 39 & (18) & 39 & (12) & 39 & 4 & WNW & 4 \\
\hline 20 & & (16) & & (21) & 36 & (11) & 36 & (11) & 36 & 3 & WNW & 3 \\
\hline 21 & 35 & (13) & 35 & (13) & 35 & (16) & 33 & (21) & 34 & 3 & WNW & 2 \\
\hline 22 & 34 & (15) & 34 & (19) & 34 & (15) & 33 & (14) & 33 & 3 & - & - \\
\hline 23 & 34 & (15) & 33 & (17) & & (17) & 35 & $(7)$ & 32 & 3 & - & - \\
\hline 24 & 33 & (14) & 33 & (10) & 33 & (10) & 32 & $\overline{(8)}$ & 31 & 3 & $\mathrm{NW}$ & 4 \\
\hline 1 & 33 & (14) & 32 & (16) & 32 & (16) & 32 & $(16)$ & 31 & 3 & - & - \\
\hline 2 & 32 & (16) & 32 & (16) & 32 & (20) & 32 & $(20)$ & 30 & 3 & - & - \\
\hline 3 & 32 & (16) & 32 & (16) & 31 & (18) & 30 & $(21)$ & 30 & 3 & WNW & 4 \\
\hline 4 & 31 & (26) & 31 & (22) & 30 & (12) & 30 & $(16)$ & 29 & 3 & - & - \\
\hline 5 & & (24) & & (19) & 29 & (19) & & (27) & 27 & 3 & - & - \\
\hline 6 & $\underline{29}$ & $\underline{(38)}$ & $\underline{\underline{29}}$ & (38) & $\underline{29}$ & $(38)$ & $\overline{29}$ & (33) & $\overline{28}$ & 3 & W & 3 \\
\hline
\end{tabular}

Remarks : 1. Date of observation : 7 8 August 1963.

Location : Najaf City, Karbala, IRAQ

2. Obs. time means time for observation.

3. Beaufort means Beaufort Scale of wind velocity.

4. Diwaniya Met. Obs. means the Diwaniya Meteorological Observatory. at the Air Port.

the soil varied from $28^{\circ} \mathrm{C}$ to $57^{\circ} \mathrm{C}$, the air temperature and the humidity at $2 \mathrm{~cm}$ height varied from $28^{\circ} \mathrm{C}$ to $47^{\circ} \mathrm{C}$ and from $34 \%$ to $7 \%$, respectively, and those at $150 \mathrm{~cm}$ height did from $29^{\circ} \mathrm{C}$ to $44^{\circ} \mathrm{C}$ and from $38^{\circ} \mathrm{C}$ to $10 \%$. Dew and other meteorologcal phenomena were not observed.

It was notable that the wind velocity observed here was almost same as that recorded at the Diwaniya Air Port, and it is possible to expect that in spite of a rather strong wind over the desert the wind over the high yield paddy fields was not strong by the effect of windbreak. Through the comparison of wind velocity observations at the Diwaniya Meteorological Observatory and at the Diwaniya Experimental Farm, where windbreak was not faciliated well, it was certified that the wind velocity in this experiment farm was just between the Meteorological Observatory and the paddy field.

An effective distance of windbreak was assessed by the observation of temperature and humidity at Amara. The temperature under the date palm grove was $39^{\circ} \mathrm{C}$ with a relative humidity of $27 \%$ and the influence of the date palm grove extended, with gradually decreasing power, for 400 metres to the leeward, where the normal desert temperature of $45^{\circ} \mathrm{C}$ with $14 \%$ humidity was reached. Therefore it is estimated that with the aid of a 1,000 metre length windbreak against the predominant wind in A1-Mishkhab, it would be reasonable to have paddy fields extending for 500 metres away from it along the line of the predominant wind.

Besides the meteorological observation, some 
observations from the view point of crop science were given. Number of panicles per square metre was more than 300 , if the weeds were controlled well, and this is at the same level of number of panicles in Japan of $312 \pm 43$. Number of grains per panicle was more than 90 and this is at the higher level than that in Japan of 78.4 \pm 7.0 . But the fertility of grain was about $50 \%$, even though the fertility in Japan is $87.6 \pm 2.7 \%$. Weight of 1,000 grains (husked) was below 20 grams and it is smaller than that in Japan of $20.8 \pm 0.8$ grams. These data mentioned above show the importance of promoting the fertility of grains and weight of 1,000 grains for the increase of rice production in Iraq. Data in Japan are cited from the author's report in 1962.

\section{Discussion and conclusion}

The final object of this report is to find ways of increasing rice production in Iraq. It is first of all necessary to find out what the limiting factors are, and then to find out ways of overcoming them. The extremely hot and dry summer climate in Iraq observed here should be very important limiting factor to rice production, and the results obtained here also show that insufficiency of water is equally important, because water is not only important as a physiological factor for the rice plants, before and after heading, but for its strongly moderating effect of the local and micro-climate of the rice field areas. The moderating effect of water on the climate is far less when the rice fields are scattered over a large area, as they are observed from Baghdad to Amara, than when many rice fields are collected together in one area, such as those surrounding Shamiah Town.

To concentrate all the rice fields in a few selected areas along the rivers and main canals would be the immediately feasible means of conserving valuable water in Iraq and would have the added advantage of modifying the micro-and local-climate of the fields making them more favourable for the growth of rice. To obtain sufficient modification of climate for the production of high yields, the rice fields area must be large, and the more rice fields are collected together in one area, the better.

The effect of surrounding the rice fields with windbreaks would be to lessen considerably the force of the desert wind over them and thus to help the normal growth of rice plant and to save water consumption. The longest effective distance of a windbreak, even of adult date palm grove, is 500 metres. So the rice field area, greater than 50 hectares should be divided into sections, and each section should be surrounded by windbreaks. No section should stretch for more than 500 metres along the line of the predominating north-west wind in summer, and if temporary windbreaks are used the distance should be less. The size of each section. should depend upon the efiective distance of its: windbreaks.

It is possible to say, taking the experience of the: desert in United Arab Republic into account, that the provision of windbreaks to protect the fields against the hot and dry desert wind is vitally necessary if any significant modification of microclimate is to be achieved. For the main windbreaks dividing the rice fields from the desert, casuarina (Casuarina Equisitifolia), or eucalyptus trees (Eucalyptus spp.) are the most useful, but for windbreaks. among the units of the rice fields, date palms are useful. To provide temporary windbreaks while the trees are growing sufficiently large to serve their purpose, such quick growing bushes as Sesbania spp. are very effective.

\section{Acknowledgement}

The author wishes to thank Mr. K. Al-Kaissi and Mr.H. Diab for technical assistance, and Mr. A. Ismail, Director General of Agricultural Research. and Projects, the Government of Iraq and Dr.J.Fuad, Director of Field Crops Division for supporting the observation. Mr. Jassim, the driver served under the author very well.

\section{References}

Buringh, PiETER (1960) : Soils and Conditions in Iraq. D. G. of Agricultural Research and Projects, Ministry of Agriculture, Iraq.

CHAO, LIEN-FANG (1959) : Report to the Government of Iraq on Rice FAO No. 1081

ITO, HIROSHI (1962): Tashu-sei Ine Ikushu-zairyo. no Seitai-kei. (Characteristics of Genetic Stocks. of Rice for Higher Yield) -in Japanese Recent Advance in Breeding III.

(1963) : The Necessity, the Possibility and the Means of Rapidly Increasing Rice Production in Iraq. D.G. of Agricultural Research and Projects, Ministry of Agriculture, Iraq.

Ministry of Communications, Iraq (1960) : Climatological Means for Iraq.

WALLEN, C.C. and G. PERRIN de BRICHAMBAUT (1962): A Study of Agro-climatology in Semi-arid and Arid Zones of the Near East. FAO. 
極高温乾燥地，イラク国における水田微気象観測の一例

伊藤博

（農林省農業技術研究所生理遺云部）

イラク国に叔ける稲の出穂前の気候は, 日中は月平均 でも $42^{\circ} \mathrm{C}$, 湿度 $20 \%$ 以下で, 稲の正常な発育を期待 することは出来ない。しかし, 全国平均の収量は低いが 高位収穫田もあり, 年々 10 万トンの米の生産があるの で，その理由を明らかにし，逆に増産の方策をたてるた めに, 水田微気象の観測を行なつた。

水田や湿地が径 $25 \mathrm{~km}$ にる及ぶ大集団を作つている シャミヤ地方では, 気温 $46^{\circ} \mathrm{C}$, 湿度 $10 \%$ の砂漠気象 が, 気温 $41^{\circ} \mathrm{C}$, 湿度 $49 \%$ 飞温和化され, 収量も高い。 径 $1 \mathrm{~km}$ 程度の水田が散在している場合には, このよう
にはつきりした気候の温和化は認められない。さらに高 位収穫田と砂漠とで 24 時間の微気象観測を行ならと, 水田とくに植被内での微気象と砂漠との差が著しく, と くに防風林による乾風の防止が気候改良に大きな効果が. あつた。稲の収量構成要素の調査結果をも吟味した結 果, 水田を集団化し, 湛水状態に保ち, さらに防風林で 保護することによつて, 水田微気象を稲の生育に適する ように改造することも可能で, これにより增産を期待す ることができる。

\section{日本農業気象学会 賛 助会員 名簿 (受付順)}

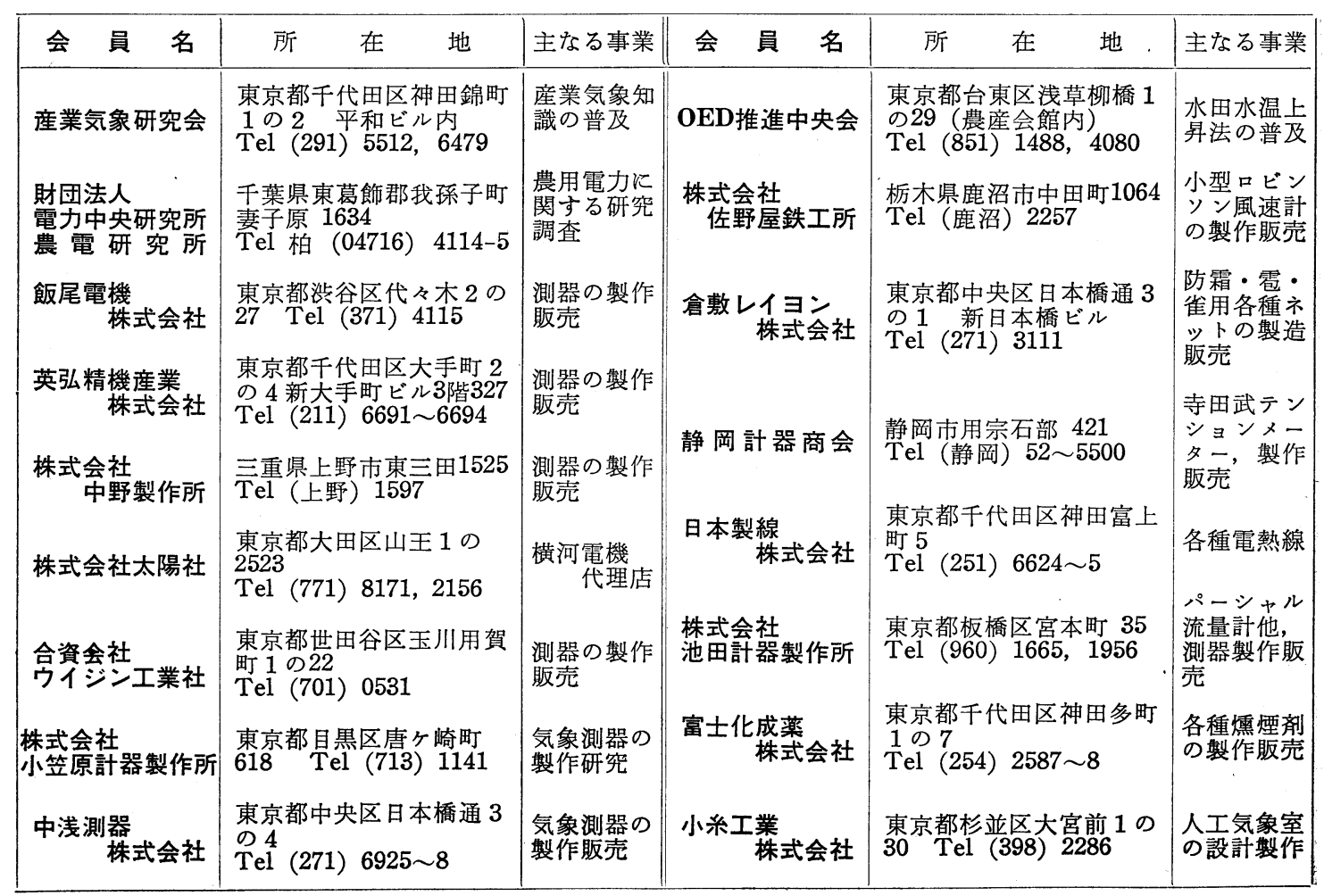

